\title{
Phosphotungstate Staining of Vaccinia Virus
}

\author{
By W. J. HARRIS aNd J. C. N. WESTWOOD \\ Microbiological Research Establishment, Porton, Wiltshire
}

(Received 23 September 1963)

\begin{abstract}
SUMMARY
Vaccinia virus subjected to various repeated treatments and then negatively stained with potassium phosphotungstate was examined with the electron microscope. To obtain reproducible results it was necessary to standardize the preparation procedure. The standarized method now recommended is that the virus should be mixed with stain before being placed on the electron microscope grids and the grids then immediately examined or dried for $1 \mathrm{hr}$ in a vacuum of at least $1 \times 10^{-3}$ torr. The staining procedure may be altered to vary the degree of penetration of stain so as to reveal either internal or external detail.
\end{abstract}

\section{INTRODUCTION}

Negatively stained preparations of purified vaccinia virus appear to contain two types of particle. This has been reported by Nagington \& Horne (1962), Noyes (1962) and Westwood et al. (1964). Westwood and co-workers showed that in fresh preparations between 80 and $90 \%$ of the virus had a beaded surface like a mulberry ( $\mathbf{M}$ form, Pl. 1, fig. 1), whilst the remainder were larger capsulated particles (C form, Pl. 1, fig. 2). They also showed that by various treatments it was possible to alter the ratio of the two types of particle in a given preparation by converting $\mathbf{M}$ forms to $\mathrm{C}$ forms. During this part of that investigation, quantitative discrepancies in the results of repeated conversion treatments indicated the necessity of standardizing the procedure for preparing specimens. This paper describes the standardization found to be necessary for reliable quantitative studies and demonstrates the errors in structural assessment that can occur if standardization be omitted.

\section{METHODS}

Virus. Dermal strains of vaccinia virus were grown on rabbit skin as described by Hoagland, Smadel \& Rivers (1940) and purified by density-gradient centrifugation by the method of Zwartouw, Westwood \& Appleyard (1962). The final deposit in each case was suspended in distilled water and its infectivity destroyed by ultraviolet (u.v.) irradiation.

Negative staining. Solutions of $2 \%(\mathrm{w} / \mathrm{v})$ potassium phosphotungstate (PTA) were used. Solutions of either $2 \%(\mathrm{w} / \mathrm{v})$ ammonium molybdate or $1 \%(\mathrm{w} / \mathrm{v})$ uranyl acetate were used in some experiments to confirm the results obtained with PTA solution.

Electron microscopy. Except where otherwise stated, carbon-covered grids were used and the virus (with or without stain) applied as drops from a pipette. Specimens were examined with a Siemens Elmiskop I operated at $80 \mathrm{kV}$, with double condenser illumination. 


\section{RESULTS}

\section{Effect of allowing virus to dry before staining}

Brenner \& Horne (1959), who originally described the negative staining method, recommended mixing together virus and stain and spraying the mixture on to coated grids. In the investigation by Westwood et al. (1964) where structure in shadowed specimens was investigated, it was considered necessary, for direct comparison, to examine virus which had been allowed to dry before staining. It was soon observed that different specimens prepared from the same virus batch showed wide variations in the ratio of $\mathbf{C}$ to $\mathbf{M}$ types of particle. Since the staining time had been standard for all specimens, it appeared that the ratio might depend upon the time for which the specimens were allowed to dry before staining.

Table 1. Vaccinia virus: variation in ratio of $C: M$ particle forms with time of drying before staining with PTA solution

$\begin{array}{cccc}\text { Virus batch } & \text { Drying time } & \begin{array}{c}\text { M form } \\ (\%)\end{array} & \begin{array}{c}\text { C form } \\ (\%)\end{array} \\ & \text { Control } & 82 \cdot 5 & 17 \cdot 5 \\ & 10 \mathrm{~min} . & 61 & 39 \\ \mathbf{2 ~ h r} & 40 & 60 \\ & 4 \mathrm{hr} & 20 & 80 \\ 2 & 24 \mathrm{hr} & 19 & 81 \\ & \text { Control } & 89 \cdot 3 & 10 \cdot 7 \\ & 30 \mathrm{~min} . & \mathbf{7 1} & \mathbf{2 9} \\ & 1 \mathrm{hr} & \mathbf{5 2} & 48 \\ & 2 \mathrm{hr} & 17 & 83 \\ & 4 \mathrm{hr} & 13 & 87\end{array}$

Table 2. Vaccinia virus: effect of type of support film on rate of conversion to $C$ form

$\begin{array}{cccc}\begin{array}{c}\text { Support } \\ \text { film }\end{array} & \begin{array}{c}\text { Drying time } \\ \text { (hr) }\end{array} & \begin{array}{c}\text { M form } \\ (\%)\end{array} & \begin{array}{c}\text { C form } \\ (\%)\end{array} \\ \text { Formvar } & \text { Control } & 84 & 16 \\ & 2 & 76 & 24 \\ & 6 & 32 & 68 \\ \text { Carbon } & \text { Control } & 77 & 23 \\ & 2 & 46 & 54 \\ & 6 & 11 & 89\end{array}$

Table 1 gives the results of experiments with two batches of virus in which the period of drying on the grid before staining was varied. The dried virus specimen was stained by immersion of the grid in PTA solution for 5 min. followed by draining and drying on the laboratory bench. The ratio of $\mathrm{C}$ to $\mathrm{M}$ forms clearly depended on the initial drying period and reached a maximum at $2-4 \mathrm{hr}$, when $15-20 \%$ of M forms remained. Further extension of the drying period apparently caused no additional conversion. The rate of conversion was decreased by preparing the specimens on grids coated with 'Formvar' instead of carbon (Table 2). Whereas evaporated carbon films are virtually non-wettable with water, freshly made Formvar films are readily wettable and apparently absorb and retain moisture for some time, so that drying takes place more slowly than on a carbon film. 


\section{Effect of delay in examination after staining}

Variations in the $\mathrm{C}: \mathrm{M}$ ratio were also observed in replicate specimens from the same virus batch (mixed with stain) prepared by the spray method of Brenner \& Horne (1959). In this case the only variable factor was the delay between preparation of the specimen and its examination with the electron microscope. The effect of varying the period of delay was therefore investigated.

Drops of virus suspension and PTA solution (mixed in equal volumes) were placed on carbon-covered grids. Some specimens were examined immediately and some left for $18 \mathrm{hr}$ before examination. It is seen from the results in Table $\mathbf{3}$ that delay in examination caused conversion of $\mathrm{M}$ to $\mathrm{C}$ forms. In addition to the typical $\mathrm{C}$ form, an intermediate form had also been produced (Pl. 1, fig. 3) in which the stain had apparently penetrated the surface 'thread' layer (Westwood et al. 1964) of the M form but had not reached the nucleoid. The continued slow penetration of stain shown by this experiment implied that sufficient residual moisture remained after drying on the laboratory bench for diffusion of P'TA to take place and suggested that specimens should be stabilized by rapid complete drying.

Table 3. Vaccinia virus: conversion to $C$ form (including intermediate form) brought about by delay in examination after staining with PTA solution

\begin{tabular}{|c|c|c|c|c|}
\hline \multirow[b]{2}{*}{ Virus batch } & \multicolumn{2}{|c|}{ Examined immediately } & \multicolumn{2}{|c|}{ Examined after $18 \mathrm{hr}$ dela } \\
\hline & $\begin{array}{c}\text { M form } \\
(\%)\end{array}$ & $\begin{array}{c}\text { C form } \\
(\%)\end{array}$ & $\begin{array}{c}\mathbf{M} \text { form } \\
(\%)\end{array}$ & $\begin{array}{c}\text { C form } \\
(\%)\end{array}$ \\
\hline $\mathbf{1}$ & $79 \cdot 5$ & $20 \cdot 5$ & 35 & 65 \\
\hline 2 & 80 & 20 & 41 & 59 \\
\hline 3 & 80 & 20 & $\mathbf{3 4}$ & 66 \\
\hline
\end{tabular}

Table 4. Vaccinia virus: results showing stabilization of virus form by vacuum drying

\begin{tabular}{|c|c|c|c|}
\hline $\begin{array}{l}\text { Virus } \\
\text { batch }\end{array}$ & & $\begin{array}{c}\text { M form } \\
(\%)\end{array}$ & $\begin{array}{c}\text { C form } \\
(\%)\end{array}$ \\
\hline \multirow[t]{4}{*}{1} & Immediate examination (control) & $82 \cdot 5$ & $17 \cdot 5$ \\
\hline & On bench for $24 \mathrm{hr}$ before examination & 48 & 52 \\
\hline & Under vacuum for $24 \mathrm{hr}$ before examination & 81 & 19 \\
\hline & $\begin{array}{l}\text { Under vacuum for } 1 \mathrm{hr} \text {, then on bench for } \\
24 \mathrm{hr} \text { before examination }\end{array}$ & $81 \cdot 7$ & $18 \cdot 3$ \\
\hline \multirow[t]{4}{*}{2} & Immediate examination (control) & 80 & 20 \\
\hline & On bench for $24 \mathrm{hr}$ before examination & 29 & 71 \\
\hline & Under vacuum for $24 \mathrm{hr}$ before examination & 75 & 25 \\
\hline & $\begin{array}{l}\text { Under vacuum for } 1 \mathrm{hr} \text {, then on bench for } \\
24 \mathrm{hr} \text { before examination }\end{array}$ & $81 \cdot 5$ & $18 \cdot 5$ \\
\hline
\end{tabular}

Table 4 shows the results of an experiment in which replicate specimens were prepared as before. Some were examined immediately, others left standing on the bench for $24 \mathrm{hr}$ before examination and the remainder vacuum-dried at $1 \times 10^{-3}$ torr. After $1 \mathrm{hr}$ half of the vacuum-dried specimens were removed from the desiccator and allowed to stand on the laboratory bench for a further $24 \mathrm{hr}$. The others were kept under vacuum for $24 \mathrm{hr}$ and then immediately examined with the electron microscope. It is apparent from the results that stained specimens can be completely stabilized by rapid vacuum drying. 


\section{Reconversion of $C$ to $M$ forms in specimens dried before staining}

As already shown, desiccation of the virus before staining leads to conversion of $\mathbf{M}$ to $\mathbf{C}$ forms. This conversion, which appears to be due to increased penetration of stain into the virus particle, may be brought about by chemical agents (Peters, 1962; Westwood et al. 1964) in which case it is irreversible. To test the possibility that the conversion following desiccation was reversible, specimens which had been allowed to dry on the laboratory bench for $2 \mathrm{hr}$ were soaked in water for $1 \mathrm{hr}$ before staining. Table 5 shows that there was a complete reconversion to give the original $\mathrm{C}: \mathrm{M}$ ratio of the specimen.

Table 5. Vaccinia virus: effect of reconstituting dried virus before staining with PTA solution

$\begin{array}{lcc} & \begin{array}{c}\text { M form } \\ (\%)\end{array} & \begin{array}{c}\text { C form } \\ (\%)\end{array} \\ \begin{array}{l}\text { Control specimen stained and examined } \\ \text { immediately }\end{array} & 90 & 10 \\ \begin{array}{l}\text { Specimen allowed to dry for } 2 \mathrm{hr} \text { before } \\ \text { staining }\end{array} & 54 & 46 \\ \begin{array}{l}\text { Specimen allowed to dry for } 2 \mathrm{hr}, \\ \text { reconstituted for } 1 \mathrm{hr} \text { before staining }\end{array} & 92 & 8\end{array}$

\section{DISCUSSION}

The experimental results clearly show that to obtain repeatable quantitative results and reliable structural assessment when examining preparations of vaccinia virus negatively stained with PTA, it is essential to standardize the preparation procedure. Differences in virus-type ratios brought about by drying before staining are clearly best eliminated by staining the virus in the wet state. Experiments have shown that the time of staining above a minimum of $30 \mathrm{sec}$. is not critical but, for some reason, optimum spreading of the PTA on carbon-covered grids appears to be obtained with a minimum staining time of $5 \mathrm{~min}$. and this was adopted as the standard procedure.

Westwood et al. (1964) concluded that the $\mathrm{C}$ form of virus appears to be a particle deficient or damaged in some way which permits penetration of stain into the nucleoidal region and reported that the proportion of $\mathrm{C}$ forms could be increased by several treatments of the virus, including exposure to ethanol. It was therefore suggested that the 'thread' layer of the $\mathbf{M}$ form might be normally impermeable to stain because of the incorporation of some lipid component. However, as it is possible to reconstitute and reconvert dried $\mathrm{C}$ form virus to $\mathrm{M}$ form, perhaps the state of turgidity of the 'thread' (or some other layer) also determines whether the virus is of the $\mathbf{M}$ or $\mathbf{C}$ form, for when turgid the layer may act as a barrier to the penetration of stain.

There appear to be two disadvantages of leaving PTA stained specimens for any length of time before examination. First, as already pointed out, there appears to be a gradual diffusion of stain into the virus; the results in Tables 3 and 4 clearly show the errors that can be encountered and the way in which they can be satisfactorily prevented. We believe that PTA on a grid quickly forms a partially 

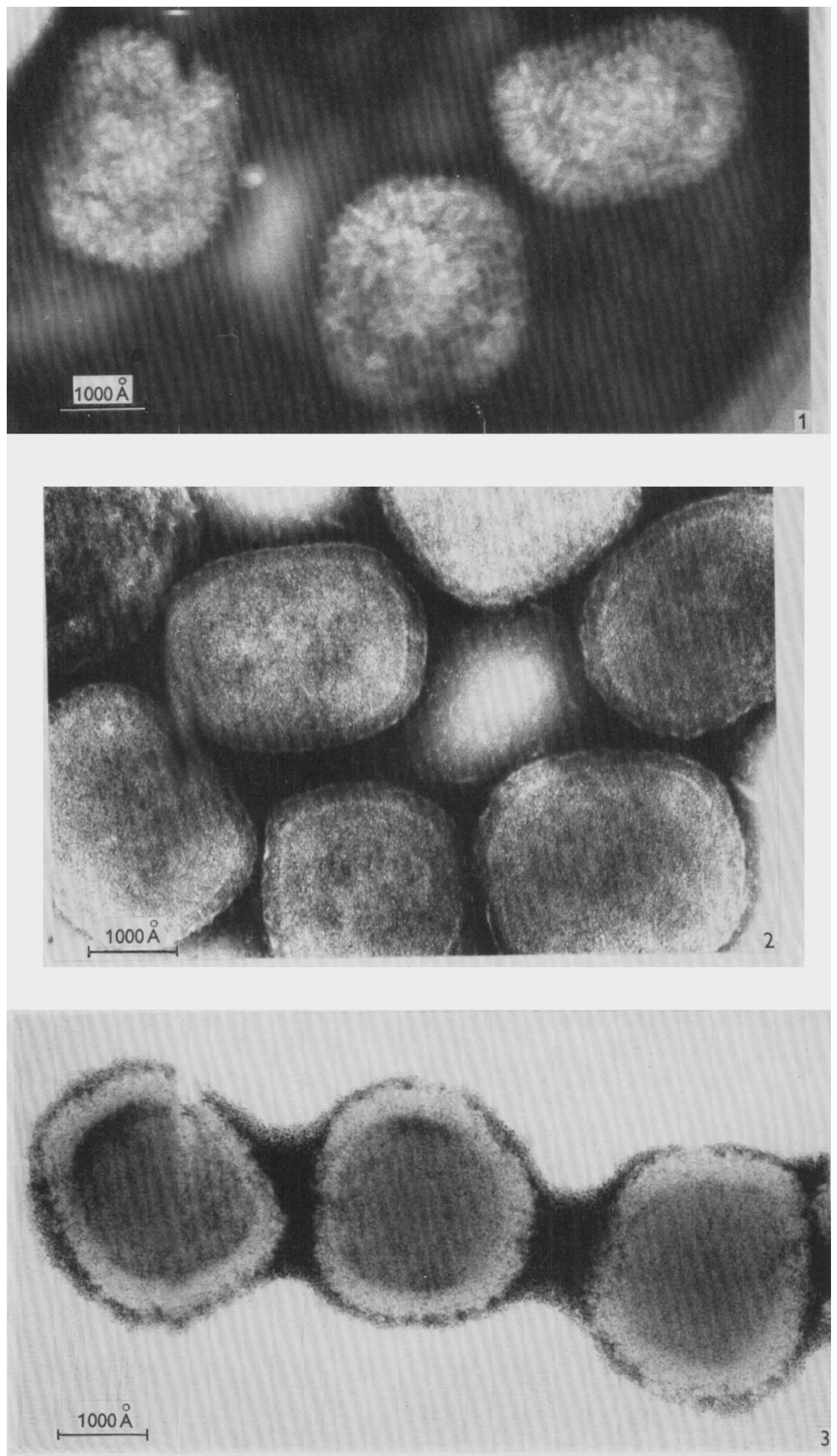
impervious skin so that it becomes increasingly difficult with time to wash away excess PTA from around stained virus. Consequently the virus particle is held in slowly drying PTA enclosed in a 'shell'; thus with the loss of turgidity in the virus due to drying, stain is slowly able to enter the virus. Intermediate forms with confusing appearance are then frequently produced. The second disadvantage of long delay before examination of the specimens is that the PTA in such specimens always appears to be very granular (Pl. 1, fig. 3). The granularity of the PTA appears to undergo change with time because in control specimens examined immediately after staining it is very much finer (Pl. 1, figs. 1, 2).

In the results quoted, the control specimens were prepared under standardized conditions which gave consistent results in replicate experiments. These conditions are: (1) virus mixed with stain for 5 min.; (2) drops of mixture from a pipette placed on carbon-covered grids; (3) immediate drying of prepared specimens either by examination with the electron microscope or by exposure for $1 \mathrm{hr}$ to a vacuum of $1 \times 10^{-3}$ torr.

The results not only stress the need for standardization of preparation technique if consistent results are to be obtained, but also suggest that the staining procedure may be varied for different purposes according to whether exclusion of stain to reveal external detail or its penetration for the study of internal structure is desired. It may well be that similar standardization is desirable for the reliable examination of viruses other than vaccinia.

\section{REFERENCES}

Brenner, S. \& Horne, R. W. (1959). A negative staining method for high resolution electron microscopy. Biochim. biophys. Acta, 34, 103.

Hoagland, C. L., Smadel, J. E. \& Rivers, T. M. (1940). Constituents of elementary bodies of vaccinia. 1. Certain basic analyses and observations on lipid components of the virus. J. exp. Med. 71, 737.

Nagington, J. \& HoRne, R. W. (1962). Morphological studies on orf and vaccinia viruses. Virology, 16, 248.

Noyes, W. F. (1962). Further studies on the structure of vaccinia virus. Virology, 18, 511.

Peters, D. (1962). Substrukturen des Vaccine-Virus. Proc. 5th int. Conf. electr. Micr. 2, S-2.

Westwood, J. C. N., Harris, W. J., Zwartouw, H. T., Titmuss, D. H. J. \& Appleyard, G. (1964). Studies on the structure of vaccinia virus. J. gen. Microbiol. 34, 67.

Zwartouw, H. T., Westwood, J. C. N. \& Appleyard. G. (1962). Purification of pox virus by density-gradient centrifugation. J. gen. Microbiol. 29, 523 .

\section{EXPLANATION OF PLATE}

Fig. 1. M form of vaccinia virus.

Fig. 2. C form of vaccinia virus.

Fig. 3. Intermediate form of vaccinia virus. 